

\section{Money, Markets and Capital}

Money and payments are familiar to everybody. Economists, however, are often at a loss in assessing the extent to which money matters. As a matter of fact, money is at the origin of the main cleavage in economic theory. Beyond sophisticated models what is at stake is whether money is just an appearance which hides the essence of economic life (value and happiness of people) or, on the contrary, the very substance of economic relations, not limited to exchanges, in which power and sovereignty are ever present.

In a first part, the author shows how fragile and shaky are the attempts made by value theoreticians to integrate money into their analysis. In a second part, he develops a rigorous alternative theory by giving strong logical foundations to a monetary analysis in the spirit of Keynes. Many important economic phenomena left unexplained by academic theory are accounted for (involuntary equilibrium unemployment), a new method in dynamics is resorted to (viability theory) and various economic relations are elucidated which are not reducible to exchange, the only one dealt with by academic theoreticians. This is the case of the wage relationship.

Although written in view of an audience acquainted with economic theory, this book can be read nevertheless by a larger circle since the technicalities have been reduced to what is strictly necessary to understand what is at stake.

Jean Cartelier is Professor Emeritus at Paris Nanterre University. His main fields of interest are general economics, money theory and history of economic thought. 
Routledge International Studies in Money and Banking

Modern Monetary Theory and European Macroeconomics

Dirk H. Ehnts

\section{Capital Flows, Financial Markets and Banking Crises}

Chia-Ying Chang

Banking and Economic Rent in Asia

Rent Effects, Financial Fragility and Economic Development

Edited by Yasushi Suzuki, Mohammad Dulal Miah, Manjula K. Wanniarachchige and S.M. Sohrab Uddin

Finance at Work

Edited by Valérie Boussard

The Development of International Monetary Policy

Christopher Warburton

Pension Fund Economics and Finance

Efficiency, Investments and Risk-Taking

Edited by Jacob A. Bikker

The Rise and Development of Fintech

Accounts of Disruption from Sweden and Beyond

Edited by Robin Teigland, Shahryar Siri, Anthony Larsson, Alejandro Moreno

Puertas and Claire Ingram Bogusz

Money, Markets and Capital

The Case for a Monetary Analysis

Jean Cartelier

For a full list of titles in this series, please visit www.routledge.com/series/SE0403 


\section{Money, Markets and Capital}

The case for a monetary analysis

Jean Cartelier

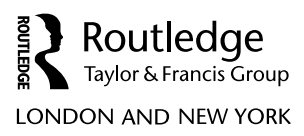


First published 2018

by Routledge

2 Park Square, Milton Park, Abingdon, Oxon OXI4 4RN

and by Routledge

7II Third Avenue, New York, NY 10017

Routledge is an imprint of the Taylor \& Francis Group, an informa business

(C) 2018 Jean Cartelier

The right of Jean Cartelier to be identified as the author of this work has been asserted by him in accordance with sections 77 and 78 of the Copyright, Designs and Patents Act 1988.

All rights reserved. No part of this book may be reprinted or reproduced or utilised in any form or by any electronic, mechanical, or other means, now known or hereafter invented, including photocopying and recording, or in any information storage or retrieval system, without permission in writing from the publishers.

Trademark notice: Product or corporate names may be trademarks or registered trademarks, and are used only for identification and explanation without intent to infringe.

British Library Cataloguing-in-Publication Data

A catalogue record for this book is available from the British Library

Library of Congress Cataloging-in-Publication Data

Names: Cartelier, Jean, author.

Title: Money, markets and capital : a case for monetary analysis / Jean Cartelier.

Description: Abingdon, Oxon ; New York, NY : Routledge, [2018] | Series: Routledge international studies in money and banking | Includes bibliographical references and index.

Identifiers: LCCN 201706I082 | ISBN 97808 I5355779 (hardback) | ISBN 978I35II 29244 (ebook)

Subjects: LCSH: Money-Philosophy. | Monetary policy. | Capital market.

Classification: LCC HG22I .C375 2018 | DDC 332.40I-dc23

LC record available at https://lccn.loc.gov/201706/082

ISBN: 978-0-8I5-35577-9 (hbk)

ISBN: 978-I-35I-I 2924-4 (ebk)

Typeset in Bembo

by Apex CoVantage, LLC 


\section{Contents}

List of figures

vii

List of tables

viii

List of schemas

ix

Introduction

\section{PART I}

Money in value theory

1 A bird's-eye view

2 Integration of money into value theory and neutrality in a nutshell

The problem of integration 18

Neutrality of money: the grail of money theory? 52

3 Money: fiat money or social device for coordination?

The essence of money 59

The incentives for going beyond academic theory 67

\section{PART II}

The case for a monetary analysis

4 Primitives of a monetary analysis

The fundamental postulates 81

Money and accounts: a close connexion 85

The minting process, a crucial element of a monetary economy 88 
5 A pure market economy: exchange relations

A market economy: main characteristics 96

Some propositions 112

The dynamics of market relations 123

6 Entrepreneurs, wage-earners and capitalists

The rationale for the differentiation of entrepreneurs and wage-earners 136

Specific properties of an entrepreneur economy 148

The level of activity: a crucial point 154

7 Some specific properties of a capitalist economy

Kalecki's principle 181

Involuntary unemployment steady-states: Solow as a special case of a monetary analysis 182

Disequilibrium dynamics: Harrod's razor-edge 187

From entrepreneur economy to finance 192

\section{Conclusion}

Some advances of the present essay 218

Economics and the plurality of social disciplines:

a suggested interpretation 222

References

Index 


\section{Figures}

2.1 Temporary equilibrium model 30

2.2 A simple overlapping generations model $\quad 32$

2.3 Best response correspondence and equilibria 41

5.1 Trajectories with $z=-2 \quad 130$

5.2 Progressive hardening of the constraint 131

5.3 A two-part viability kernel 132

5.4 Viability and credit 133

7.1 Involuntary employment steady-states 186

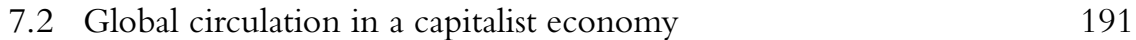

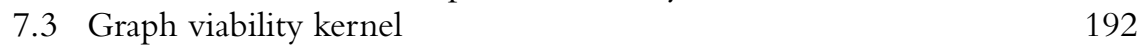

$\begin{array}{lll}7.4 & \text { Balance-sheets beginning } & 200\end{array}$

7.5 Balance-sheets backwards looking 202

$\begin{array}{ll}7.6 & \text { Steady-states with dividends } \\ 7.7 & \text { Patabola }\end{array}$

$\begin{array}{lll}7.7 & \text { Parabola } & 210\end{array}$

7.8 Viability kernel, the parabola curve and an example of heavy solution $\quad 212$

$\begin{array}{ll}7.9 \text { Locus } z^{\prime}=0 & 214\end{array}$ 


\section{Tables}

1.1 Different consequences of $p_{m}=0$ according to the techniques of transactions which are considered

4.1 Real and monetary approaches

5.1 Matrix of voluntary and constrained payments and mutual commitments to future payments

6.1 Payment matrix 1

6.2 Production technique, consumption and investment

152

7.1 Correspondence between standard notation and matrix payment

183

7.2 Payment matrix in a capitalist economy

201

7.3 Flows accounts

203

7.4 Extension of Kalecki's principle to an economy with capitalists

204 


\section{Schemas}

5.1 Money circulation in a market economy 112

6.1 Money domestic circulation $\quad 145$

6.2 Money circulation in an entrepreneur economy 146

6.3 Global money circulation in an entrepreneur economy 153 
$\because$ Taylor \& Francis

Taylor \& Francis Group

http://taylorandfrancis.com 


\section{Introduction}

Money pervades our everyday life. ${ }^{1}$ We use it to finance our purchases, taxes and other expenses. We consult our various accounts in euros or dollars to check our economic situation (personal bank accounts, system of payments accounts and so forth). From an economic point of view, we are nothing but nodes in a huge network of inter-related accounts. Corporate and individual enterprises, households, foundations, associations and so on, observe, analyze and manage themselves using more or less sophisticated accounting. Any physical or moral person living in our society is or can be described by their money accounts.

These accounts are not an anecdotal or innocuous description of what individuals or collective entities do. If insolvency or illiquidity show up, then the people concerned are put in danger of being expelled from the economy. Accounts are performative. More than reflecting economic activity, recorded transfers of dollars from an account to another are economic activity itself; figures in these accounts are directly or indirectly written down by the current flows of payment taking place between economic agents. Most of these flows transit through banks. It is one of the reasons why banks play a central role in economic activity. They are the "great accountants" and perhaps are more than that, since they have some control over monetary flows. Money, accounting, banks, etc. seem to be the stuff economic activity is made of.

However, when academic theoreticians come to think about "economic reality" they dismiss accounts and monetary quantities. They resort instead to a sophisticated representation where goods or commodities are at the centre of the scene and money, if at all, is nothing but a special commodity called fiat money. No nominal unit of account is required. Wealth is expressed in an arbitrary numéraire and defined as a scalar product of a real prices vector by a commodity allocation vector. In order to restore a monetary image of economic relations, academic economists introduce fiat money amongst commodities and try to determine its price using the value theory they have adopted for other commodities. This exercise is known as integration of money into value theory.

Conceiving money as a commodity (however special) may appear strange in regard of what ordinary economic life suggests. The everyday economic relations that we can observe seem to belong to a complex system in which 
rules, institutions and commercial laws play an important role. Trying to give an account of such a payment system by resorting to the typical abstractions of value theory (commodity space, preferences, relative values expressed in a numéraire) may appear to be pure nonsense. For value theoreticians it is quite the opposite since these abstractions are the only scientific way to get to the essence of economic relations - and economic relations are not what a naive observer may believe them to be. Money hides what economic relations are about. Money has to be discarded at the first step because it is not a relevant expression of wealth. We have to build an appropriate value system based on goods or commodities conceived of as the natural basis on which societies rely. People are commodity producers and consumers; they are interested in real wealth, not in nominal magnitudes. They have preferences for certain commodities and are free of money illusion.

Moreover, according to academic economists, exchange is the basic relation between economic agents. Pure competition - since no agent can exert an influence on what happens in the market - is the benchmark. Desired allocations are realized only when individual actions are mutually compatible at equilibrium prices. The main task of economic theory is to determine these relative prices, and the way prices are determined reveals the essence of economic life: difficulty of production in Classical and Ricardo-Sraffian theory, relative scarcity in modern Neoclassical theory. In any case, money cannot be understood but as a (special) commodity whose relative price is ruled by the same principle other commodities are subject to.

Wealth is not nominal but real. English Classical economists conceived it as the capacity to produce and to yield profit. Modern academics are concerned with social welfare being conceived as a configuration of individual preferences and not as the power of the Prince. Both principles go without saying for most academic economists. It is worth recalling, however, that it has been a long-standing matter of controversy to decide whether a nation's power and opulence or a society's happiness was, or should be, the main object of political economy. The controversy between Thomas Mun and Dudley North, wellknown by historians of economic thought, is a nice example of it. This debate is still on the agenda even if not explicitly. Let us briefly remind the reader of their relevant positions.

Thomas Mun (1664), ${ }^{2}$ a partisan of the balance of commerce theory, maintained that an excess balance was the means to increase the wealth of a country (England's Treasure by Foreign Trade is the title of his most famous book). Consider a square matrix of payments where the $h^{\text {th }}$ row (column) shows the expenses (receipts) of a country $h$ addresses to (coming from) other countries. Each country exhibits a positive balance if receipts (the sum of the column) exceed expenses (the sum of the rows) or negative otherwise. The algebraic sum of these balances is identically zero. According to the rules of the game of trade, a country with a positive balance gets richer comparatively to the others. If payment flows are made in gold or silver, enrichment takes the form of an increase 
in precious metals, very useful for financing diplomacy or wars. If payments use credit - money issued by monetization of capital - then enrichment takes the form of financial assets. In any case, these gains of trade are the way merchants and nations get richer. Thinking this way is far from stupid.

Sir Dudley North (1691), however, observed that an excess balance of trade means that the quantity of commodities (measured in money) flowing out of the country is greater than the one flowing into it. The consequence is clear: individuals living in a country have less quantity of commodities (measured in money) to consume. The country, i.e. its inhabitants are impoverished. Thinking this way makes sense too!

Who is right? Both of them! If wealth is conceived of as a relative advantage over other traders, Mun is right. If, on the contrary, wealth is the utility or happiness given by command over commodities, North is closer to the truth. The fact is that economic theoreticians have en masse decided to follow North rather than to develop Mun's argument. North and Mun may be taken as the emblems of the two major strands in economic analysis that Schumpeter (1954) proposes to distinguish in his History of Economic Analysis, respectively the real analysis or value theory and the monetary analysis.

Real analysis proceeds from the principle that all the essential phenomena of economic life are capable of being described in terms of goods and services, of decisions about them, and of relations between them. (. . .) Monetary analysis introduces the element of money on the very ground floor of our analytical structure and abandons the idea that all essential features of economic life are represented by a barter-economy model.

(History of Economic Analysis, pp. 277-278)

We will adopt Schumpeter's general view even if we will be more radical about the definition of monetary analysis: money will be considered not only as important but, in some sense, as the true substance of economic relations.

Schumpeter's observation has not received a sufficient attention by academic economists. They too easily agree about an empirical definition of the field of economics as simultaneously encompassing operations on commodities and monetary flows while they restrict that definition to commodities when they build their theoretical models. Whatever the school they claim to belong to, if they were asked about that schizophrenia, they would deny it. They would consider that economic theory does deal in fact with commodities and money. After reflection, some of them involved in monetary theory would accept that money is in fact excluded from modern value theory - the so-called integration of money into value theory is known as being a spiny task - but they would absolutely refuse to admit that a symmetric approach - excluding commodities and dealing with money flows only - would make sense. At most they would concede that during the pre-scientific era of economics, some authors, dubbed "mercantilists" by Adam Smith, have followed such a foolish track. Needless to say, such 
an orientation would be meaningless nowadays. Even theoreticians claiming to be true to Keynes and being critical of the mainstream for its neglect of money do not go as far as recommending an exclusion of commodities from the field of economics. They affirm that money is ever present together with commodities in economic life as in theory without providing any motivation for doing so without asking themselves about the legitimacy of such an accumulation of postulates. They assert that money is not neutral without establishing the conditions for neutrality. They seem not to be motivated by an inquiry into what makes their claims acceptable. Most of them are concerned more by empirical phenomenon than by giving strong logical foundations to their work.

The present state of the art is a little bit paradoxical. While most of people, including academic economists, proceed as if commodities transactions and money flows are present in economic theory, a critical examination of most theoretical works convinces that such a co-existence is by no means effective and legitimate. As we shall see, (a) money finds no room in value theory, (b) it does not make sense to postulate a commodity space in addition to a payment system postulate. Most theoreticians are rarely so radical: value theoreticians try to find some room for money in their models while defenders of a monetary analysis exceptionally renounce to take for granted the existence of an a priori given commodity space. As a rule, the former are more rigorous than the latter. But this should not prevent us from taking seriously Schumpeter's proposition (more seriously than he did himself!) and from sharply distinguishing between different theories according to the predominance of one or the two postulates: commodity space or payment system (money).

It appears useful to cross that dichotomy with another distinction: do economic agents have the same status - it is the case in a pure exchange economy or have they different conditions?

Doing so we get a grid based on these two criteria:

- The first one concerns the more or less hidden founding abstraction: a commodity space or a payment system.

- The second one concerns economic agents status; are entrepreneurs and wage-earners treated as homogeneous or heterogeneous.

Crossing these criteria gives four cases which correspond to some of our next chapters:

1 Commodity space and homogeneous condition (not to be confused with identity of endowments and preferences) for entrepreneurs and wage-earners: general competitive equilibrium theory illustrates the case. Integration of money into that value theory is examined in Chapters 1,2 and 3 (Part I). We maintain that in spite of very sophisticated models built by very talented authors, money has not been satisfactorily integrated into value theory. General competitive equilibrium theory (and more generally 
mainstream theory) remains still based on a commodity space postulate. It will be shown how the logical structure of that piece of real analysis is an obstacle to account for some fundamental features of a market economy.

2 Commodity space and heterogeneous condition between entrepreneurs and wage-earners: the typical example is Ricardian (and more generally English Classical economics) and Neoricardian theory (not studied in this book).

3 Payment system with homogeneous agents: pure market economy (Chapter 5). We show that a basic property of a market economy which is not accounted for in mainstream theory (a true decentralization of economic agents) receives the attention it deserves allowing us to deal with out-ofequilibrium positions. A specific dynamic approach is suggested in consequence. Commodities are not postulated but derived from the payment system postulate.

4 Payment system with heterogeneous condition between entrepreneurs and wage-earners: Keynes is the outstanding author here. We show that the heterogeneous condition follows from how economic agents stand vis-à-vis the payment system. This allows us to give precise foundations to Keynesian economics (Chapters 6 and 7). A comparison with what is going on in Keynesian economics at large (and especially SFC models) makes clear what a logically founded monetary analysis (without commodity space postulate!) may bring forth.

The subtitle of the present book - the case for a monetary analysis - gives a clear idea about our motivation. In order to give some substance to our motivation we are required:

- to prove that money integration into value theory has failed even if interesting propositions have been established thanks to the many efforts of general equilibrium theoreticians

- to build a logically coherent theory of both a market and a capitalist economy independently of any value theory (i.e. without postulating a commodity space).

In this book we try to partially contribute to that double task. Partially because, as Keynes justly reminds us, "the difficulty lies, not in the new ideas, but in escaping from the old ones, which ramify (. . .) into every corner of our minds" (General Theory, p. xxiii). The more or less implicit postulate of any value theory - an a priori given commodity space - appears to be so evident that it hardly needs any justification. It seems almost impossible and nonsensical to do without it. Neoricardians, although radically opposed to Neoclassical theory, share with it that postulate. Marx indulges himself in accepting it also. It is not easy to go counter a dominant way of thinking.

A further obstacle to overcome is the prevalence today in the academic world of the empirical studies over theory. As we shall see in due course, Keynesians 
of all sorts are more eager on showing that capitalist economies are not working satisfactorily than giving convincing reasons for the weakness of mainstream theory. More than often invoked by them, the lack of realism is an ambiguous critique since it takes for granted that reality is in some sense already known. If this were true why bother with theory? The affirmation of the predominance of demand over supply - a metaphor more than a clear-cut statement - may hardly be taken seriously either. Expressing that idea as an insufficient effective demand looks better but leads most often Keynesians to emphasize the occurrence in the "real world" of under-employment equilibria which is by no means a hard blow to mainstream when the cause is attributed to oligopolistic competition or other "realistic assumptions".

Whatever the difficulties to be overcome may be, we have to embark upon that double task assuming that most readers would agree that the two fundamental choices a theoretician has to decide for are (a) whether real or monetary analysis should be adopted, and (b) whether entrepreneurs and wage-earners should or should not be treated on the same footing.

The book is about theory, not about the history of economic thought. A detailed history relating how value theoreticians have solved the problems they have raised is far beyond the purpose of this book. Not only will the RicardoSraffian tradition be ignored but many interesting debates in Neoclassical theory, or more generally academic theory, will also not be carefully studied. One of our aims is rather to understand the logical relations existing between the different issues about money characteristic of value theory (existence of a monetary equilibrium, money neutrality, the essence of money, etc.). An alternative way of expressing this objective is that we take a critical examination of the main propositions or statements that value theory has brought up so far.

Put in a nutshell, modern academic theory of money, which belongs to the real analysis, has gone as far as possible up to the point where it is no longer possible to go further without a radical change for an alternative view about economic theory, i.e. for a monetary analysis. This last approach has a long tradition and can be traced back to mercantilists and Steuart (1767). It leads to a very different view of what economics is about and of what its relations with other social disciplines could be. The case for a monetary analysis is due to a failure of the real one to take into account the fundamental properties of a decentralized economy. It is not easy to be aware of that failure since it comes as the paradoxical outcome of some great analytical advances in the field of general competitive equilibrium theory. Paradoxical because these great improvements towards rigour came jointly with the shrinkage of the field covered by analysis. A well-known example is the negative results of the global stability study that emerged in the 1970s which led to the abandoning of any research about the way a market economy could arrive at an equilibrium through a decentralized process of successive positions of disequilibrium. In the same manner, the great advances in academic money theory make easier to see its limits. An inadequacy of fiat money as the basic notion and an inappropriate view of the quantity of 
money as a parameter are two outstanding negative features calling for a change of approach.

The importance given in this book to a critique of the academic theory of money requires that the reader have some clear ideas of its basic reasoning and propositions. The first part of the book is devoted to that task. Technicalities will be reduced to what is strictly necessary for a good understanding of what modern academic theory says about money. What matters is less the details of the models, although they cannot be entirely neglected, than the concepts and the way basic questions are formulated. It is only at this level that an alternative theory makes sense and may be discussed. The alternative theory in question monetary analysis - is by no means new. It belongs to the long tradition initiated by the so-called mercantilists and Steuart.

The other and more important aim of this book is to precisely defend and illustrate the monetary analysis. We do not attempt to give a detailed account of how many authors have progressively developed the monetary analysis. Some special steps will be mentioned in passing - John Law (1705) and Steuart (1767) being the most outstanding figures from the past and Wicksell (1935), Schumpeter (1970), Hawtrey (1919) and Keynes (1973) in more modern times. But, in any case, a reformulation of the monetary analysis is in order. It will be done more in accordance with modern standards, namely a quasi-axiomatic presentation allowing a clear discussion and a rational separation between what is due to philosophical convictions and prejudices (barely debatable) and what results from a logical and consistent reasoning (which is possible to seriously discuss).

Consequently, the book is in two parts and dedicated respectively to a critical examination of modern academic theory of money and to a presentation of an alternative theory based on the idea that money, market and capital are intertwined concepts.

At this point of the introduction an important remark must be made. Even if we think that a monetary analysis is more fruitful and more relevant than value theories, we do not maintain that the former brings better answers than the latter to the questions the existence of money commonly raises. As a matter of fact value theories and monetary analysis do not address the same issues. One contribution of this book, if any, is to make it clear that value theory and monetary analysis are not in competition about particular common monetary questions but on $a$ general attitude towards what economic theory is and what it is about.

Value (or real) analysis to money has been adopted by the academic profession (or at least by those economists concerned with money theory). In that spirit, a good theory must first of all justify that money be introduced amongst commodities. This is done by proving the existence of a general equilibrium with a positive price for money. Then, it must be checked whether or not the introduction of money modifies the main properties of the economy (the so-called question of money neutrality). That money has a positive price at equilibrium is not enough; its presence in the economy has to be accounted for. This is achieved by comparing non-monetary equilibria with monetary ones. Money 
is said to be essential (in the sense of Wallace) if the latter is better than the former from a welfare point of view. In this case, it is possible to make precise what "frictions" money remedies and what makes it essential: absence of double coincidence of wants, lack of information about commodities' quality, impossibility of commitment, etc.

This methodology is a powerful and versatile one. Many important results are due to it. Its weakness lies in its unduly restricted field of validity. All the models alluded to above incorporate equilibrium conditions amongst their equations. Consequently, their solutions are necessarily equilibrium ones. By construction, out-of-equilibrium situations are left unexplained and undescribed. But there are no convincing reasons to exclude such situations from the study of decentralized economies. Quite the opposite! For more than two centuries, the problem of global stability of market economies has been the main concern of authors. From Cantillon to Marx, Classical economists have inquired into the gravitation of market prices around natural ones and into the general overproduction crisis. From Walras (1988) to Arrow and Hildenbrand, general competitive equilibrium theoreticians have tried to demonstrate the global stability of general equilibrium until Sonnenschein (1972), Mantel (1974) and Debreu (1974) definitively showed the impossibility of it. As a result, the longstanding issue at stake for all value theories - the property of self-regulation of market economies - has been left unexplored since the beginning of the seventies. What common wisdom considers a typical feature of our economies - the so-called market sanctions and adjustments - is out of reach for real analysis theoreticians!

Investigating the reasons for that unacceptable oversight leads one to realize that its origin lies mainly in the way money is conceived of. Money theory and market theory are so strongly inter-related that the former should be built in mind of the latter (Cartelier, 2007).

The second alternative, the monetary analysis, is scarcely adopted nowadays. For the economists following this track, market economies cannot be thought of without money. Consequently they take it for granted, without bothering with its (logical) origin and genesis. The existence of a general equilibrium with a positive money price is no longer a relevant issue, no more than neutrality. The differences between the general visions on which value and monetary analysis rely, respectively, are responsible for the diversity of the issues which are dealt with. Monetary analysis makes sense, by comparison with value theory, because it is not restricted to viewing economic relations as exchange ones. It encompasses every type of social relations mediated through money. A major issue is the issuance of a means of payment and how different people are situated from that point of view. Monetary relations are thought of as not reducible, neither for exchange nor for power. They are beyond exchange and predation. They must be studied for themselves.

Accordingly, what has to be discovered are the rules of the game played by humans when their relationships are mediated through money. Chess players are human beings. When they play chess they are more than pure human 
beings. They have also to comply with chess rules. Nothing of interest can be said about a game by an observer who does not know the rules of chess. But, while it is easy to learn these rules in a book, the rules of monetary mediation are written nowhere. The present book is a tentative effort to modestly remedy that absence. The main purpose of monetary analysis is to make them explicit. Discovering the dynamic properties of a monetary economy is part of that issue. Such a program belongs to an older tradition starting with the so-called mercantilists and encompassing some very different authors but who all share a common concern. It is the case for the writers listed above, John Law, James Steuart, (partially) Marx, Wicksell and the Swedish School, Hawtrey and Keynes.

Real and monetary analysis offer advantages and difficulties. Are there criteria for choosing between them?

A pure methodological argument should be avoided at this point. Some commentators argue that philosophical or methodological considerations are decisive. It is a commonplace to maintain that academic theoreticians adhere to methodological individualism which makes them start from supposed independent, egoistic and rational individuals groping into Nature without any a priori social bond. Not only commentators but theoreticians themselves share that view. However, a straight examination of how general competitive equilibrium theory effectively proceeds shows that such imputation is not valid. In fact, despite their methodological or philosophical convictions, theoreticians have to presuppose something common to all individuals before they could articulate any proposition about them. They have first to assume a commodity space (Debreu's Euclidian space $R^{l}$ ) which is common knowledge. Without that commodity space, it would be impossible to describe individuals as they are in that theory, i.e. as initial endowments (points of $R^{l}$ ) and preferences functions (defined on $R^{l}$ ) as well as production techniques.

The commodity space is the common language individuals use to communicate their demands and supplies to others. It is also the language theoreticians use to describe the economy and to demonstrate its properties. Being logically prior to the assumption of individual economic agents, the commodity space may be called an institutional assumption.

Two other institutional assumptions are necessary for general competitive equilibrium theory to be consistent: (a) for the study of equilibrium existence, an auctioneer (a non-individual entity having no endowment and no preferences) must propose parametric prices; (b) for the study of global stability, another auctioneer (or the same one!) must modify parametric prices according to an a priori given rule, improperly called the "law of supply and demand". That so-called "law" is nothing but an assumption and, as it has been shown, an (inefficient) algorithm for solving the system of excess-demand equations (Saari \& Simon, 1978). These assumptions may be interpreted (as Walras did) as a social mechanism - competition - triggered by an institution. ${ }^{3}$

In brief, value theory, as represented by general competitive equilibrium, should not be condemned for its supposed methodological individualism or for inappropriate methodological considerations. 
At this point, the reader may ask: what use is it to show that general equilibrium theoreticians comply with methodological principles very different to those usually imputed to them and that they adopt, even if not consciously, those of their opponents? The answer is straightforward: a critique based on the methodological argument above is a poor one. If this academic theory is to be criticized (and it certainly should be), it is not for the absence of institutional hypothesis but for the irrelevance of those which are effectively made. As a sign or consequence of that irrelevance, general equilibrium theory describes an economy very different to what is generally considered as a market economy. The question is not whether institutional hypothesis should or should not be made, but to determine the ones which will allow us to give an interesting and fruitful account of a decentralized economy.

Here, the question of money is crucial. Presupposing money as an institution - i.e. a given set of rules - instead of a commodity space (with or without fiat money) radically changes our perspective about economy. Money is an important mediation in the mutual relations that individuals entertain amongst themselves. Taking money as granted is not adding an institutional hypothesis to academic theory but replacing the commodity space postulate with a nominal unit of account postulate which will prove to be more relevant. It will lead us to make the mode of issuance and cancellation of the means of payment - the minting process - the central institution of market economies. Here too, this may interpreted as replacing an inefficient institutional hypothesis - the so-called "law of demand and supply" does not guaranty global stability of general competitive equilibrium - with a more relevant one.

In what follows, what will be at stake is an assessment of the relative fruitfulness and the relative limits of validity of the real and monetary analysis. Far from accumulating anathemas against one or the other, our purpose is to broaden the scope of discussions around money theory. If it seems rather clear that money theory relying on a real analysis has limited perspectives - which makes absolutely necessary the search for an alternative - it is also true that its available results deserve to be known and discussed, if only for generalizing and overtaking them.

\section{Notes}

1 It is my great pleasure to recognize that this book owes much to a collaboration over more than thirty years with Carlo Benetti (as the bibliography testifies). Moreover I am grateful for all his remarks and suggestions after a reading of a first version of this book. Perry Mehrling and Ghislain Deleplace have made many useful and important suggestions. I am also grateful to them and to three anonymous reviewers. The usual disclaimer applies.

2 Names followed by a date refer to the bibliography appended at the end of the book.

3 Institutions are understood as supra-individual entities by authors defending a holistic point of view. We abstain from that view in the present essay, less because we disagree but because such a view is by no means necessary to our argument. Institutions here will be any set of rules which has not to be micro-founded even if these rules concern only individual inter-relations. 


\section{References}

Aglietta, Michel \& Orléan, André , (1982), La violence de la monnaie, PUF, Paris.

Aglietta, Michel \& Orléan, André , (2002), La monnaie entre violence et confiance, Odile Jacob, Paris.

Amir, R. , Sahi, S. , Shubik, M. \& Yao, S. , (1987), "A Strategic Market Game with Complete Markets", in CFDP 813R, Cowles Foundation, Yale University Press, New Haven, CT.

Araujo, Luis \& Camargo, Braz , (2015), "Limited Monitoring and the Essentiality of Money", Journal of Mathematical Economics, 58, May, 32-37.

Araujo, Luis \& Guimaraes, Bernardo , (2014), "Coordination in the Use of Money", Journal of Monetary Economics, 64, May, 38-47.

Aubin, Jean-Pierre , (1997), Dynamic Economic Theory: A Viability Approach, Springer Verlag, Berlin.

Aubin, Jean-Pierre , Bayen, Alexandre \& Saint-Pierre, Patrick , (2011), Viability Theory, New Directions, Springer, Heidelberg.

Aydinonat, Emrah , (2011), "Explaining the Origin of Money, Interdisciplinary Perspectives", in New Approaches to Monetary Theory, edited by H. Ganssmann , Routledge, London, pp. 46-66.

Benetti, Carlo , (1985), "Economie monétaire et économie de troc: la question de l'unité de compte commune", Economie appliquée, 1.

Benetti, Carlo , (1996), "The Ambiguity of the Notion of General Equilibrium with a Zero-Price for Money", in Money in Motion, edited by G. Deleplace \& E. Nell , MacMillan, London, pp. 365-376.

Benetti, Carlo , Bidard, Christian, Klimovsky, Edith \& Rebeyrol, Antoine , (2012), "Reproduction and Temporary Disequilibrium: A Classical Approach", Metroeconomica, 63 (4), 614-633. Benetti, Carlo \& Cartelier, Jean , (1980), Marchands, salariat et capitalistes, Maspéro, Paris, p. 207.

Benetti, Carlo \& Cartelier, Jean , (1987), “Monnaie, valeur et propriété privée”, Revue économique, 38 (6), 1157-1170.

Benetti, Carlo \& Cartelier, Jean , (1999), "Market and Division of Labour: A Critical

Reformulation of Marx's View", Rivista di Politica Economica, April-May, 119-139.

Benetti, Carlo \& Cartelier, Jean , (2001), "Money and Price Theory", International Journal of Applied Economics and Econometrics, 9 (2), 203-223.

Benetti, Carlo , Klimovsky, Edith \& Rebeyrol, Antoine , (2014), "Monetary and Physical Observable Magnitudes in Sraffa's System", mimeo.

Bezemer, Dirk , (2009), "Banks as Social Accountants: Credit and Crisis through an Accounting Lens”, MPRA Paper No. 15766 (http://mpra.ub.uni-muenchen.de/15766/).

Binmore, Ken , (2005), Natural Justice, Oxford University Press, Oxford.

Boltanski, Luc \& Thévenot, Laurent, (1991), De la justification, Gallimard, Paris.

Bridel, Pascal , (1997), Money and General Equilibrium Theory, Edward Elgar, Cheltenham.

Cantillon, Richard , [1755], (1955), Essai sur la nature du commerce en général, INED, Paris.

Cartelier, Jean , (1991) "Marx's theory of value, exchange and surplus value: a suggested interpretation", Cambridge Journal of Economics, 15 (3), 257-270.

Cartelier, Jean , (1996), "Chômage involontaire d'équilibre et asymétrie entre salariés et nonsalariés", Revue économique, 47 (3), 655-665.

Cartelier, Jean , (2004), "Budgetary Constraints, Stocks and Flows in a Monetary Economy: Keynes's Economics Once More", in Money, Credit and the Role of the State, edited by R. Arena , Asgate, Aldershot.

Cartelier, Jean , (2007a), "The Hypostasis of Money: An Economic Point of View", Cambridge Journal of Economics, 31 (2), 217-233.

Cartelier, Jean , (2007b), "Money and Markets as Twin Concepts?", in Money and Markets, a Doctrinal Approach, edited by A. Giacomin \& M. C. Marcuzzo, Routledge, Abingdon, UK, pp. 79-95.

Cartelier, Jean , (2010), "Money Is the Scribe of a Market Economy", in Money and Calculation, edited by M. Amato , L. Doria \& L. Fantacci , Palgrave Macmillan , pp. 16-33.

Cartelier, Jean , (2011), "Money and Sovereignty, a Comparison between Hobbes and Modern Money Theory", in New Approaches to Monetary Economics and Theory, edited by $\mathrm{H}$.

Ganssmann, Routledge, London. 
Cartelier, Jean , (2014a), "Endogenous Money in an Elementary Search Model: Intrinsic Properties versus Bootstrap", in Economics and Other Branches: In the Shade of the Oak Tree, edited by R. Baranzini \& F. Allisson, Pickering \& Chatoo.

Cartelier, Jean , (2014b), "The Positive Surplus Hypothesis: Social versus Physical Objectivity", in Towards a New Understanding of Sraffa: Insights from Archival Research, edited by R.

Bellofiore \& S. Carter, MacMillan.

Cartelier, Jean , (2016), L'intrus et l'absent, Essai sur le travail et le salariat dans la théorie économique, Presses de l'Université Paris-Ouest.

Cartelier, Jean \& Müllers, Katarina , (1994), "Viability in a Keynesian Model: A Preliminary Approach", IIASA Working Papers.

Cartelier, Jean \& Saint-Pierre, Patrick , (2012), "A Viability Model for a Monetary Economy", Communication to the Conference "Around Viability Boundaries", December 12-14, Paris, UPMC, Marie Curie Actions \& C\&O.

Caverzasi, Eugenio \& Godin, Antoine , (2013), "Stock-Flow Consistent Modeling through the Ages", University of Pavia, Pavia, Working Paper No. 745.

Clower, Robert W. , [1965], (1984), "The Keynesian Counter-Revolution: A Theoretical

Appraisal", reprint in Money and Markets, Essays by Robert Clower, edited by D. A. Walker ,

Cambridge University Press, Cambridge.

Clower, Robert W. , [1967], (1984), "A Reconsideration of the Micro-Foundations of Monetary

Theory", reprint in Money and Markets, Essays by Robert W. Clower, edited by D. A. Walker,

Cambridge University Press, Cambridge.

Cohen, J. , (1972), "Copeland's Moneyflows after Twenty-Five Years: A Survey", Journal of Economic Literature, 10 (1), 1-25.

Copeland, M. A. , (1949), "Social Accounting for Moneyflows", The Accounting Review, 24 (3), 254-264.

Debreu, Gérard , (1959), Theory of Value: An Axiomatic Analysis of Economic Equilibrium, Cowles Foundation, monograph 17, Yale University Press, New Haven, CT.

Debreu, Gérard , (1974), "Excess Demand Functions", Journal of Mathematical Economics, 1, 15-21.

Deleplace, Ghislain , (1996), "Does Circulation Need a Monetary Standard", in Money in Motion: The Post Keynesian and Circulation Approaches, edited by G. Deleplace \& E. Nell , MacMillan, London, pp. 305-329.

Deleplace, Ghislain , (2017), Ricardo on Money: A Reappraisal, Routledge, Abingdon, UK, p. 417.

Drèze, Jacques \& Polemarchakis, Herakles , (2000), Monetary Equilibria, CORE, Louvainla_Neuve.

Gale, Douglas , (1982), Money: In Equilibrium, Cambridge University Press, Cambridge. Ganssmann, Heiner , (2001), "La monnaie comme fait social", Sciences de la Société, (52), 137-157.

Geneakoplos, John , (1987), "Overlapping Generations Model of General Equilibrium”, in The New Palgrave, edited by J. Eatwell , M. Milgate \& P. Newman, MacMillan.

Glustoff, Errol , (1968), "On the Existence of a Keynesian Equilibrium", Review of Economic Studies, 327-334.

Godley \& Lavoie, Marc , (2007), Monetary Economics: An Integrated Approach to Credit, Money, Income, Production and Wealth, Palgrave Macmillan, p. 530.

Graeber, David , (2011), Debt, the First 5000 Years, Melville House, London.

Grandmont, Jean-Michel , (1983), Money and Value, Cambridge University Press, Cambridge.

Gurley \& Shaw , (1960), Money in a Theory of Finance, Brookings Institution, p. 385.

Hahn, Frank , (1965), "On Some Problems of Proving the Existence of an Equilibrium in a Monetary Economy", in Monetary Theory, edited by R. W. Clower , Penguin Modern Economics, 1969.

Hahn, Frank. (1971), "Equilibrium with Transaction Costs", Econometrica, 39, 417-439.

Hawtrey, Reginald G. , (1919), Currency and Credit, Longmans, Green and Co, London, p. 393. Hayek, Friedrich , [1931], (1967), Prices and Production, Augustus Kelley.

Hellwig, Martin , (1993), "The Challenge of Monetary Theory", European Economic Review, 37, 215-242.

Hicks, John , (1937), "Mr. Keynes and the 'Classics' a Suggested Interpretation”, Econometrica, $5(2)$. 
Hume, David , (1970), "Of Money", in Writings on Economics, edited by E. Rotwein , The University of Wisconsin Press, Madison.

Iwai, Katsuhito , (1988), "The Evolution of Money: A Search-Theoretic Foundation of Monetary Economics", University of Pennsylvania CARESS Working Paper No. 88-03.

Jacob, C. , (1972), "Copeland's Moneyflows after Twenty-Five Years: A Survey", Journal of Economic Literature, 10 (1), 1-25.

Jacques, Jean-François \& Rebeyrol, Antoine , (2009), "Primitive Accumulation, Growth and the Genesis of Social Classes", Metroeconomica, 2.

Jones, R. A. , (1976), "The Origin and Development of Media of Exchange", Journal of PoliticalEconomy, 84, 757-775.

Keynes, John Maynard , [1930], (1973), “A Treatise on Money”, in The Collected Writings of John Maynard Keynes, (volumes 5, and 6), MacMillan, St Martin Press.

Keynes, John Maynard , [1936], (1973), "The General Theory of Employment, Interest and Money", in The Collected Writings of John Maynard Keynes, (volume 7), MacMillan, St Martin Press.

Kiyotaki, Nobuhiro \& Wright, Randall , (1993), "A Search-Theoretic Approach to Monetary Economics", The American Review, 83 (1), 63-77.

Kocherlakota, Narayama R. , (1998), "Money Is Memory", Journal of Economic Theory, 81, 232-251.

Kocherlakota, Narayama R. \& Wallace, Neil , (1998), "Incomplete Record-Keeping and Optimal Payment Arrangements", Journal of Economic Theory, 81, 272-289.

Lagos, R. \& Wright, R. , (2005), "A Unified Framework for Monetary Theory and Policy Analysis", Journal of Political Economy, 113, 463-484.

Lakomski-Laguerre, Odile , (2002), Les institutions monétaires du capitalisme, L'Harmattan, Paris, p. 365.

Lavoie, Marc , (2014), Post-Keynesian Economics: New Foundations, Elgar, Cheltenham. Law, John , (1934), "Money and Trade in Oeuvres complètes", ed. by P. Harsin , (3 vol.), Sirey, Paris, [1705].

Luhmann, Niklas , (1984), "Die Wirtschaft der Gesellschaft als autopoietisches System", Zeitschrift für Soziologie, 13 (4), Oktober, 308-327.

Luhmann, Niklas , (1989), Ecological Communication, University of Chicago Press, Chicago. Luhmann, Niklas , (1995), Social Systems, Stanford University Press, Stanford.

Mantel, R. , (1974), "Homothetic Preferences and Community Excess Demand Functions", Journal of Economic Theory, 7, 197-201.

Marx, Karl , [1867], (1976), Capital, Penguin Books, London.

Matsuyama, Kiminori , (2006), "The Lawrence R. Klein Lecture: Emergent Class Structure", International Economic Review, 47 (2), 327-360.

Mehrling, Perry , (2011), The New Lombard Street, How the Fed Became the Dealer of Last Resort, Princeton University Press, Princeton, NJ, p. 174.

Menger, Carl , (1892), "On the Origin of Money", Economic Journal, 2, reprint in ( R. M. Starr ed.), General Equilibrium Models of Monetary Economies, Academic Press, 1989.

Morishima, Michio , (1992), Capital \& Credit, Cambridge University Press, Cambridge.

Mun, Thomas , [1664], (1895), England's Treasure by Forraign Trade, MacMillan and Co, New York.

Niehans, Jürgen , (1978), The Theory of Money, John Hopkins University Press, Baltimore.

North, Dudley , [1691], (1907), Discourses upon Trade: Principally Directed to the Cases of the Interest, Coinage, Clipping, Increase of Money, J. Hollander, Baltimore.

Oresme, Nicolas , (1990), Traité monétaire, Treatise on money (1355), Édition trilingue juxtaposée Latinus-Français-English, Editions Cujas, Paris.

Ostroy, J. M. \& Starr, R. M. , (1974), "Money and the Decentralization of Exchange", Econometrica, 42 (6), 1093-1113, reprint in General Equilibrium Models of Monetary Economies, edited by R. M. Starr, Academic Press, London, 1989, pp. 131-169.

Patinkin, Don , (1965), Money, Interest and Prices, (2nd edition), MIT Press, Cambridge, MA, p. 640.

Patinkin, Don , (1987), "Walras's Law", in General Equilibrium: The New Palgrave, edited by J. Eatwell , M. Milgate \& P. Newman, MacMillan. 
Piccione, Michele \& Rubinstein, Ariel , (2007), "Equilibrium in the Jungle", Economic Journal, 117, July, 883-896.

Rebeyrol, Antoine , (1999), La pensée économique de Walras, Dunod, Paris.

Rupert, Peter , Schindler, Martin , Shevchenko, Andreï \& Wright, Randall , (2000), "The SearchTheoretic Approach to Monetary Economics: A Primer", Economic Review, 36 (4), 10-28.

Saari, D. \& Simon, C. , (1978), "Effective Price Mechanisms", Econometrica, 53, 1117-1131.

Sahi, S. \& Yao, S. , (1989), "The Non-Cooperative Equilibria of a Trading Economy with

Complete Markets and Consistent Prices", Journal of Mathematical Economics, 18, 325-346.

Schumpeter, Joseph A. , (1954), History of Economic Analysis, edited from manuscript by E. B.

Schumpeter, Oxford University Press, New York.

Schumpeter, Joseph A., (1970), Das Wesen des Geldes, edited and introduction by F. K. Mann , Vandenhoeck \& Ruprecht, Goettingen.

Seabright, Paul , (2006), "The Evolution of Fairness Norms: An Essay on Ken Binmore's Natural Justice", Politics, Philosophy \& Economics, 2 (5-1), 33-50.

Shapley, L. S. \& Shubik, M. , (1977), "Trade Using One Commodity as a Means of Payment", Journal of Political Economy, 85, 937-968.

Shi, Shouyong , (2006), "Viewpoint: A Micro-Foundation of Monetary Economics", Canadian Journal of Economics, 39 (3), 643-688.

Simmel, Georg , [1907], (1990), The Philosophy of Money, (2nd edition), Routledge, London. Smith, Adam , [1776], (1996), An Inquiry into the Nature and Causes of the Wealth of Nations: The Glasgow Edition of the Works and Correspondence of Adam Smith, (volumes 1 and 2), Clarendon Press, Oxford.

Sonnenschein, Hugo , (1972), "Market Excess Demand Functions”, Econometrica, 40, 549-563.

Sorin, Sylvain , (1996), "Strategic Market Games with Exchange Rates", Journal of Economic Theory, 69, 431-446.

Starr, Ross , (2011), General Equilibrium Theory: An Introduction, Cambridge University Press, Cambridge.

Steuart, James , [1767], (2015), An Inquiry into the Principles of Political Economy, (2 volumes), Liguori Editore, Napoli.

Trejos, A. \& Wright, Randall , (1995), "Search, Bargaining, Money and Prices", Journal of Political Economy, 103, 118-141.

Tsiang, S. C. , (1966), "Walras' Law, Say's Law, and Liquidity Preference in General Equilibrium Analysis", International Economic Review, 7, 329-345, reprint in Finance Constraints and the Theory of Money, edited by M. Kohn , pp. 133-151.

Ulgen, Faruk, (ed.) (1996), New Contributions to Monetary Analysis, the Foundations of an Alternative Economic Paradigm, Routledge, Abingdon Oxon, p. 259.

Veendorp , (1970), "General Equilibrium Theory for a Barter Economy", Western Economic Journal, 8, March, 1-23.

Wallace, Neil , (2001), "Whither Monetary Economics?”, International Economic Review, 42 (4), 847-869.

Walras, Léon , [1874], (1988), Eléments d'économie politique pure, Oeuvres économiques complètes d'Auguste et Léon Walras, (volume 8), Economica, Paris.

Werner, Richard , (2014), "How Do Banks Create Money, and Why Can Other Firms Not Do the Same? An Explanation for the Coexistence of Lending and Deposit-Taking", International Review of Financial Analysis, 36, 71-77.

Wicksell, Knut , (1935), Lectures on Political Economy, (2 volumes), George Routledge, London.

Williamson, Steve \& Wright, Randall , (1994), "Barter and Monetary Exchange under Private Information", American Economic Review, 84, 104-123. 